\begin{tabular}{l|l} 
Variants & $\begin{array}{l}\text { Variants } \\
\text { The Journal of the European Society for Textual } \\
\text { Scholarship }\end{array}$
\end{tabular}

$14 \mid 2019$

Varia

\title{
Textual Editing, Shakespeare's Metre and the Reader on the Clapham Omnibus
}

\section{Peter Groves}

\section{(2) OpenEdition \\ Journals}

\section{Electronic version}

URL: http://journals.openedition.org/variants/1002

DOI: 10.4000/variants. 1002

ISSN: 1879-6095

\section{Publisher}

European Society for Textual Scholarship

\section{Printed version}

Number of pages: 117-138

ISSN: 1573-3084

\section{Electronic reference}

Peter Groves, "Textual Editing, Shakespeare's Metre and the Reader on the Clapham Omnibus », Variants [Online], 14 | 2019, Online since 10 July 2019, connection on 14 November 2019. URL : http:// journals.openedition.org/variants/1002 ; DOI : 10.4000/variants.1002 


\section{Textual Editing, Shakespeare's Metre and the Reader on the Clapham Omnibus}

Peter Groves

Abstract: Just as in recent years many editors have paid insufficient (or inconsistent, or even contradictory) attention to the authority of the metre in editing early modem play-texts, so more recent editions have begun to discard even the rather basic assistance that has traditionally been supplied to the metrically unsophisticated reader: the Arden 3 editions, for example, no longer indicate the syllabic status of preterite suffixes in the text (perhaps fearing that the occasional grave accent might frighten the horses), and Jonathon Bates' recent RSC edition rejects the helpful practice, normal since Edmond Malone and George Steevens, of indicating the structure of shared lines by indentation, on the cogent grounds that the First Folio didn't do it. Ironically, this retreat from the authority of the metre has coincided with large advances, based in part upon linguistics, in our understanding of how metre works. But if metre is not some arid formality but rather a signifying system, this kind of negligence is doing that reader a disservice. This paper will explore some of the ways in which editors might discreetly assist the reader in grasping metrical and prosodic variation (where such variation seems relevant or important), and in exploring (without oppressing the reader with unnecessary detail) the kinds of editorial choices offered by two equally but variously substantive witnesses, such as Q2 and FI Hamlet: one role of the editor here is to draw attention to meaningful variation while filtering out mere noise.

ONE OF THE ROLES of an editor of a widely-read early modern author like Shakespeare is to mediate between the inherent difficulties of the language and the intelligent but non-scholarly reader. Among the difficulties such a reader faces is the metre - and the metre of the plays, written for professional actors working under the poet's guidance, is considerably more complex than that of his poems, employing whole categories of variation that are absent from his non-dramatic verse. Yet it cannot be ignored: Shakespeare's metre is an important signifying system for creating and reinforcing meanings in the theatre, and in the reader's mind, full of what John Barton calls "stage-direction in shorthand" $(1984,25)$, coded instructions or suggestions for performance (see Groves 2013, passim). The editor's task is not to prescribe certain readings, but to enable metrically unsophisticated readers to make appropriate choices in reading, by making visible the less obvious ways in which metre and prosody structure the rhythm of the lines; it is the purpose of this paper to explore the principles under which this might be done, and to suggest a relatively unobtrusive way of doing it. 
Critics are rightly suspicious of attempts to reconstruct the intentions of dead (or living) authors, in part because of the necessary indeterminacy of linguistic meaning and its complex interactions with cultural contexts. Metre, however, represents a special case where authorial intentions (conscious or otherwise) are broadly recoverable, simply because it is such a narrow code: an interaction between a relatively simple set of rules and a highly determined suite of constraints (the prosodic phonology of English). Legitimate choices involving question of meaning occasionally arise, but these are matters to flag in a footnote. It is true that some readers, even when shown the range of possible authorial intentions generated by the code, may choose to disregard them and do their own thing instead; this is no reason, however, to withhold this information from those who wish to try the rhythms the poet seems to have intended.

An obvious objection to this project is that we still have no scholarly consensus about many aspects of Shakespeare's metre. But neither do we have such a consensus on some basic questions about the editing of his texts. Could, for example, Q1 Hamlet be a 'memorial reconstruction' - that is, do such things even exist? But the fact that there is no consensus in key questions does not inhibit editors from producing new editions, nor should it: let a thousand flowers bloom, and let the intellectual market decide. All an editor can do, to put it another way, is to mount cogent arguments for his or her view (and try to maximize consensus where possible). Perhaps the broadest consensus about metre lies in the two propositions that (a) a prototypical pentameter consists of ten syllables, alternately unstressed and stressed, and (b) many lines deviate from this prototype. The notation I am proposing merely records objectively determined deviations from the prototype: the controversies lie in how such deviations should be interpreted.

A wide consensus about the metre could be achieved by using the familiar traditional Latin-derived system of scansion with its spondees and pyrrhics, but such a consensus would come at too great a price: metre is a systematic organization of prosodic phonology, but traditional scansion has a grossly inadequate understanding of prosodic phonology and no principled way of distinguishing metrical from unmetrical lines. If your taxonomy cannot tell rats from mice, it cannot constitute a descriptive account of either. Moreover, using classical terminology brings with it a subtler kind of baggage: the unconscious assumption that metrical form is (as in Latin) baked into the text of the verse, and that therefore "the verse-shape of a poem remains completely independent of its variable delivery" (Jakobson 367). This precept is perfectly well-founded for any language where the metre is encoded entirely at the level of syntax and of the phonological structure of syllables, such as classical Latin. If English metre is so encoded, then it too should be automatically communicated merely by speaking the verse-text as though it were prose. Yet anyone who has sat through amateur Shakespeare knows that this is not the case, and it certainly did not seem so to the earliest analysts of English metre, writing long before the hardening of traditional metrics into an orthodoxy (see Groves 1999). Though they show 
much fumbling and disagreement, they are united by two things: their interest in the question of well-formedness or metricality, and their tendency to see English metre as co-operatively produced in the act of reading: as something negotiated, that is, in performance (and by "performance" here I mean simply verbatim reading, out loud or subvocalized). For the Elizabethan theorists, metre is directly not a property of texts or verses as such but of appropriate utterances of verses, and the reader's task is one not of passively registering metrical form but of actively reconstructing it through some form of performative prosodic intervention. Consider figures 6.1 and 6.2 below: Gascoigne objects to 6.1(b) not because it doesn't happen to be a pentameter, but because it can't be made into one: for him, metre is a sensible pattern of alternating prominences to be manifested in the utterance of the line, and the job of the poet is to contrive the verse so "you wreste no worde from his natural and vsuall sounde" so "that all the wordes [. . .] be so placed as the first sillable may sound short or be depressed, the second long or elevate, the third shorte, [. . .] etc." $(1575,294$, emphasis mine). Figure 6.1(b) thus violates our expectations not of metre but of language: if we are to reproduce the iambic pattern in uttering it we must stress the second syllable of understand, "which is contrarie to the naturall or vsual pronunciation" (295). In the same way, Daniel rejects 6.2(b) not because it doesn't happen to sound like a heroic line, but because "you cannot make [it] fall into the right sound of a verse [. . .] unlesse you [. . .] misplace the accent" (1603, H3v; emphasis mine). These theorists locate unacceptability in the relation between the structure of the verse and its possible performances: almost any verse can be made metrical in performance, that is, but if the cost is too radical a degree of linguistic distortion (and literary verse is far less tolerant of such distortion than the demotic variety), the verse is not well made.

The main method of recording such deviations from the prototype is metrical pointing, or the provision of orthographic cues to metrical congruence, which is the fit between potential metrical structures and the prosodic form of the line. It is helpful, for example, to indicate in some way which vowels in a line do not "count" in the metrical shape. This is not because Shakespeare's pentameter is rigidly decasyllabic: clearly it isn't, in particular towards the end of his career (if it were, there would be much less of a problem). The point is rather that in order to grasp the metrical form - and thus the basic rhythm — of a line we need to be able to relate the string of actual syllables to the underlying structure of ten syllable-positions: to know when a position contains one, two or even zero syllables. This can be clarified through performance, out loud or in the head, but in order to perform - and thus to read - the line appropriately we need to understand its metrical congruence.

Yet just as in recent years many editors have failed to take the evidence of the metre into consideration in the actual process of editing (or have done so inconsistently or even incorrectly), some of the most recent editions have begun to discard even the rather basic metrical pointing that has traditionally been supplied to readers: the Arden third series editions, for example, no longer 
indicate in the text the syllabic status of preterite suffixes, that information being relegated to a footnote, where those who need it will (for that reason) feel no need to look for it. The neophyte who reads Romeo's line "Hence 'banished' is banished from the world" (RJ 3.3.19) ${ }^{1}$ in a non-pointed edition will not only hear it as prose - or, worse, as rhythmically unintelligible pentameter - but will miss the way the first, formal, expanded use of the word ('ba-ni-shĕd'), echoing Friar Laurence's use of it four lines earlier, holds it up, as it were, in scare-quotes, as a rebuke to the perceived glibness of the Friar.

The editorial justification for abandoning this helpful practice in Arden 3 (and Arden editions are models that others are likely to follow) is that "[u]nfamiliar typographic conventions" present "obstacles to the reader" (Thompson and Taylor 2006, xv). But all conventions, however useful, are necessarily unfamiliar when first encountered: this doesn't seem like a sensible reason to discard them. In any case, a reader who is tackling Shakespeare in a scholarly edition is tackling real obstacles, and is unlikely to be deterred by the occasional diacritic. However, Bate and Rasmussen's recent RSC edition of Shakespeare's Complete Works (2007) doesn't even claim that excuse for ignoring the valuable convention, normal practice for well over two centuries, of indicating the structure of shared lines by indentation; since shared lines often indicate the quick uptake of cues and short lines the reverse, this information is important. The RSC editors, however, "have abandoned this convention, since the Folio does not use it" $(2007,58)-$ an argument which, extrapolated as a general principle, would obviate much of the duty of an editor, dull or otherwise. It is, surely, one role of an editor to do certain helpful things that the original text didn't.

Strangely, this retreat from metrical pointing has coincided with large advances, based in part upon a linguistic understanding of prosody, in our knowledge of how English prosodic systems work. To put it another way, deviation from the prototypical pentameter is now for the most part an objective, linguistically describable phenomenon, even though our personal knowledge of it as readers may be (as with other linguistic systems) largely tacit and thus unavailable to introspection. In what follows I will be using my own Base and Template scansion, a post-generative synthesis, which describes how the prosodic structure or "base" of a line may (or may not) be accommodated to one or more of a number of pre-existing metrical patterns, or "templates" (see Groves 1998 or 2013 for a full account). The prototypical pattern consists of five feet (a descriptive economy - one could equally speak of ten syllable-position), each composed of a weak or "offbeat" syllable-position (" $w$ ") followed by a strong or "beat" position ("S"): transformation rules allow one to create new patterns by adding an extra offbeat at the end of a template (the so-called "feminine" ending) and by switching positions: either reversing the strong and weak positions within a foot or swapping them between adjacent feet, provided that in each case the switched pair is followed by an unswitched position (the Switch Limitation

1 References to Shakespeare (other than to F1) are to Riverside Shakespeare edition (Evans 1974). 
Rule). A reversal pushes a beat one position to the left, a swap one position to the right, producing templates such as "S-w w-S S-w w-S w-S" as in (expected beats italic, actual beats bold) "Gently to hear, kindly to judge our play", Henry V 1.0.34) or "w-S w-S w-S w-W s-S-o" (as in "The ditty does remember my drown'd father" (Tempest 1.2.406). A number of mapping rules specify how prosodic bases - to simplify a little, sequences of lexically stressed (A, B) and unstressed (O) syllables and pragmatically accented $(\mathrm{O})$ syllables — may and may not be mapped onto one of the fifty-six possible templates ${ }^{2}$ Crucially, an unstressed syllable adjacent to a stressed or accented syllable within an intonational phrase is 'dominated' (a status symbolized by a lowercase "o"), which means that it cannot carry a beat. If (to simplify slightly) one can map a base onto a legitimate template without placing an o-syllable in an S-position, the line is metrical. If it can only be so mapped onto a template that violates the Switch Limitation Rule, the line is metrical but irregular.

This system can explain historical judgments of metrical congruence. To illustrate: as I mentioned earlier, contemporaries of Shakespeare drew attention to the fact that of the following similar pairs in figures 6.1] (Gascoyne, 1575) and 6.2 (Daniel, 1603) the first is metrically acceptable and the second not. In traditional metrics the only way to distinguish them has been the reader's intuition, or what Daniel called a "iudiciall eare" (H3v), but a base-and-template scansion makes the difference explicit (the unmetrical mappings are bolded and underlined; switches that violate the Switch Limitation Rule are italicized):

\begin{tabular}{c|ccc|c|cc|c|c|c}
\hline I & \multicolumn{2}{|c|}{ understand } & your & meaning & by & your & eye. \\
\hline o & B & o & A & o & A & o & O & o & A \\
w & S & w & S & w & S & w & S & w & S \\
\hline
\end{tabular}

(a)

\begin{tabular}{c|cc|c|ccc|c|c|c}
\hline Your & meaning & $\mathrm{I}$ & \multicolumn{2}{|c|}{ understand } & by & your & eye. \\
\hline $\mathrm{o}$ & $\mathrm{A}$ & $\mathrm{o}$ & $\mathrm{O}$ & $\mathrm{B}$ & $\mathrm{o}$ & $\mathrm{A}$ & $\mathrm{o}$ & $\mathrm{o}$ & $\mathrm{A}$ \\
$\mathrm{w}$ & $\mathrm{S}$ & $\mathrm{W}$ & $\underline{\mathrm{S}}$ & $\mathrm{S}$ & $w$ & $\mathrm{~S}$ & $\mathrm{w}$ & $\mathrm{w}$ & $\mathrm{S}$ \\
\hline
\end{tabular}

(b)

Figure 6.1

2 "B" represents secondary stress within polysyllables, and stress in function words (capability, between, this); "ö" represents a syllable that may be elided. Lowercase "a" represents a subordinated stress, like that of "old" in "old dog" (default enunciation). 


\begin{tabular}{c|c|c|c|cc|cc|c|c|c}
\hline Though & Death & doth & ruine, & Virtue & yet & preserves. \\
\hline o & A & o & A & o & A & o & A & O & A \\
W & S & W & S & w & S & w & S & w & S \\
\hline
\end{tabular}

(a)

\begin{tabular}{c|c|c|cc|cc|c|cc}
\hline Though & Death & doth & consume, & Virtue & yet & preserves. \\
\hline o & A & o & o & A & A & o & A & o & A \\
W & S & W & S & W & S & w & S & w & S \\
\hline
\end{tabular}

(b)

Figure 6.2

To put it another way, a weak beat (an unstressed syllable in S-position) needs to be protected by a "buffer" from domination by a neighbouring stress: a buffer is either an unstressed syllable (which absorbs the domination) or a major syntactic break (which blocks it). Thus by in 6.1(a) is buffered by ing and your.

Metrical congruence may be objectively determinable, but clarifying it may not always be easy: in a text like Shakespeare's, with its complex history of transmission, there will be times when an editor is faced (as in other areas) with intractable material. Nevertheless, one should start from the principle that Shakespeare doesn't, on the whole, write unmetrical lines, since this would defeat the purpose of using metre (though he does, very occasionally, write irregular ones - there are three, for example, in the first 1,000 lines of The Tempest). It is scarcely bardolatry (pace Whitworth 1991, 126) to grant Shakespeare, on the evidence, a degree of metrical skill, and to assume in the first instance that unmetrical lines or passages in the earliest texts represent not slips on his part (since these are readily rectified in the process of writing) but error or interference in transmission. As Stanley Wells has said, "[w]e should pay our poet the compliment of assuming that he cares for metrical values, and be willing to emend where the surviving text is demonstrably deficient" $(1984,50)$.

For this reason, editors should (ceteris paribus) choose a variant that is metrical over one that is not, and where there is only one witness they should prefer an emendation that renders an unmetrical line metrical if it can be achieved through changing only what Greg called "accidentals" — semantically indifferent variation in "punctuation, word-division and the like" $(1950,21)$. Modern editors are, it is true, less interventionist than their predecessors, more aware of the complex social and collaborative process behind the production of play-texts and so less likely to emend them in the name of restoring the author's presumed intentions. If a passage is grammatical and makes sense, the modern editor will not, on the whole, try to improve it. But metre, like syntax, is a public code, and when an editor successfully re-segments a mislineated passage like 
F1 Macbeth TLN 1068-913 (3.1.79-90) into demonstrable pentameters, he or she is not attempting to recover some unverifiable authorial intention, but rather is aligning the text with the set of possible structures generated by that code, just as when editors unanimously choose Q2's "When he the ambitious Norway combated," (Hamlet 1.1.61) over F1's ungrammatical "When th' Ambitious Norwey combatted" (TLN 77). The procedure makes no claim, for example, to distinguish between authorial text and metrically competent collaboration or emendation.

So what sort of assistance should an editor give the neophyte? While the Arden 3 editions throw in the towel too early, it is true that for the beginner too much help can become an encumbrance, and (as with footnotes) one risks alienating more advanced readers by telling them what they already know. For this reason, the proposed editorial assistance is divided into two levels: basic (i.e. self-evident in its purpose) and advanced (requiring some instruction). Editors can choose their level depending on the kind of edition they are producing; electronic editions, of course, could hide or reveal on command different levels of assistance. The symbols, mainly super- or subscripted, are fairly unobtrusive, and readers who do not wish to learn what they mean can simply ignore them.

I want to begin with something that properly belongs to the advanced category of pointing, but which will be useful to mention here so that it may inform subsequent scansions. This is the marking of metrical structure, or phonologically obligatory switches; this is essential to metrical congruence but should be done unobtrusively. I propose a preceding "<" for phonologically obligatory reversals (superscripted to be less obtrusive), "> " for swaps, in each case immediately preceding the beat-bearing syllable; it will also be useful to identify the epic cesura - an extrametrical offbeat preceding a major syntactic break — with a "(": Miranda confesses to Ferdinand "Nor have I seen / < More that I may > call men, than you, good friend, / And my >dear fa(ther: how features are abroad / I a m skilless of;" (Tempest 3.1.50ff.); to King Edward's claim to have reversed the death-sentence on Clarence, Richard responds "But he, poor man, by your >first order died" (Richard III 2.1.88). Some lines with swaps may alternatively be realized with reversals: instead of "And my >dear father", for example, one might read "<And my dear father". As in the case of other optional reversals ("Nor have I seen" vs " < Nor have I seen"), however, indicating such alternatives would place an unnecessary cognitive load on the process of reading: it is perhaps better to let readers discover them for themselves, or relegate such information (where it makes a difference) to a footnote.

In terms of marking metrical structure, it will also be helpful to indicate some unstressed (weak) beats — but only those where there might otherwise be confusion - with a breve: "<Call in the messengĕrs < sent from the Dolphin" (Henry V 1.2.221); "The cloudy messengĕr "turns me his back" (Macbeth 3.6.41). A breve may help the neophyte confused by a long string of unstressed syllables, but not just the neophyte: I have heard professional actors accent the following

3 Citations of the First Folio follow the Through-Line Numbering (TLN) system. 
lines as "What art thou that usurp'st this time of night?" (Hamlet 1.1.46, Tony Richardson's 1969 film), "I will not be denied. Sweet heart, look back." (Titus Andronicus 1.1.481, BBC version), "And what should I do in Illyria?" (Twelfth Night 1.2.3, BBC version). Not only are these performances unmetrical: in ignoring Barton's "stage directions in shorthand" they represent inappropriate or impoverished readings. In the first of these Horatio sounds merely annoyed ("Not another ghost!") rather than horrified ("What ărt thou that usurp'st this time of night?"); the second sounds petulant, inappropriately so for the imperious Queen of the Goths ("I will not be denied; ' sweetheart, look back."); and the third misses the poignant antithesis with the following line: "And what should $\breve{I}$ do in Illýria? / My brother, hĕ is in Elýsium".

Returning to basic assistance, the simplest thing that can be done to clarify metrical congruence is to indicate in the text (rather than the notes) the unfamiliar lexical stress-patterns that characterize about 100 of Shakespeare's words (see Groves 2013, 165-70, for a list); currently this is almost never done, so that a reader puzzled by the apparent movement of lines like "Care is no cure, but rather corrosive" (Henry VI, Part 13.3.3) or "To both their deaths shalt thou be accessary" (Richard III 1.2.191) has to hunt for a footnote and thus break the flow of reading. The metrically unsophisticated reader who isn't puzzled by Elizabethan stressing (and so will not seek the footnote) has even more need of the unobtrusive assistance of a harmless diacritic or two ("<Care is no cure, but rather córrosıve"; "To both their deaths shalt thou be áccessăry"); such readers will by these means be covertly familiarized with the shapes of the pentameter ${ }^{t}$

More complex than stress is the problem of prosodic elasticity, the variable length of certain phonological words in speech due to the optional shedding of weak vowels ${ }^{5}$ Vowels that are retained by the metre where they might have been contracted should be marked with a dieresis ( $\ddot{a}, \ddot{e}$, etc.): “And, be assur'd, you'll find a diffërence" (Henry V 2.4.134); "And is't not pity, $\mathrm{O}$ my grievëd friends," (King John 5.2.24). To the breve-marked vowels we should add the syllabic semivowels $\breve{r}$ and $l$ : Henry, for example, is trisyllabic in "Is Cade the son of Henřy the Fift," (Henry VI, Part 2 4.8.34), and fire is disyllabic in "<Dashes the fiře out. < $\mathrm{O}$, I have su'ffer'd" (Tempest 1.2.5); handling is trisyllabic in "A rotten case abides no handling" (Henry IV, Part 2 4.1.159) 6

$4 \quad$ Unfamiliar polysyllabic proper names should be marked for stress because they are a frequent source of confusion. Readers usually assume that such names will be paroxytonic, but those tempted to sabotage the metre with 'ProsPEro' and 'HippoLYta" will pronounce Próspero and Hippólyta without difficulty (see Groves 2013, 171-76). Sounded final -es should also be indicated with / $\breve{\text { } /: ~ I ~ h a v e ~ h e a r d ~ N i ́ o b e ~ r h y m e ~ w i t h ~ g l o b e . ~}$

5 A phonological word consists of a word and any associated clitics: the phrase $a$ shoe-in or thou art is one phonological word.

6 Compare the old music-hall song by Fred Murray and R. P. Weston, “I'm 'Enery the Eighth, I am". In some cases, words that were elastic for the Elizabethans have become inelastic in contemporary English, so that the short form has become the only available one. There are three kinds of archaic expansions: archaic desyncopation, as in "That croaks the fatal entřance of Duncan" (Macbeth 1.5.39); "The parts and graces of the wrestler" (As 
There are two kinds of vowel-contraction: excision and elision. An excised vowel disappears completely, as in the case of contracted preterites or aphetic forms, and its excision is marked by an apostrophe (banish'd, aggriev'd, 'gainst). An elided vowel, however, need not - and usually should not - completely disappear in phonetic terms, which is why elided vowels should remain in the text, but be superscripted. Thus contracted $g o^{e} s t$ shouldn't rhyme exactly with most, because the elided vowel retains a ghostly presence and contracted minister(s) in "May be a cow ${ }^{\mathrm{a}} \mathrm{rd}^{\prime}$ ', whose min ${ }^{\mathrm{i}}$ sters would prevail" (Antony and Cleopatra 3.13.23) should be pronounced somewhere between the noun minster and the fully trisyllabic expanded form in "How sweetly you do ministĕr to love" (Much Ado about Nothing 1.1.312). In any case an elided vowel (unlike an excised one) always retains a ghostly presence in the verse, due to our knowledge of the language, and these presences play an important part in keeping the prosody of the line lively 7 Some of the most important kinds of elasticity (from the perspective of editing) involve function words, which are frequently subject to aphetic contractions like 'gainst, 'twixt, 's, ' $m$, 'd, and so on. Function-word contractions are typically excisions ('gainst, let's, she'd, I've, Sarah's [a fool], life's), but where contraction brings two vowels together there is also the possibility of elision (usually, synaloepha): she ${ }^{h a} d, I^{h a}$ ve, $\operatorname{Sarah}^{i}$ s.

In the case of syncopation and syneresis both long and short forms should be indicated in editing; this may seem redundant, but redundancy is an advantage in communication systems, particularly to someone trying to determine metrical congruence on the fly. Take, for example, a line like "Pernicious Protector, dangerous Peer" (2H6 2.1.21) or "Young, valiant, wise, and (no doubt) right royal" (R3 1.2.244); such lines on a first reading will seem problematic to those familiar with iambic pentameter (they are both fluffed in the BBC adaptations of those plays). This is because we naturally read the initial Pernicious as Pernic ${ }^{i}$ ous ("w-S w"), only to find that the following $S$ falls (impossibly) on a dominated syllable, Pro-. Similarly, it is natural to begin "Young, val'ant, wise," (because of a sensible heuristic procedure that encourages us to map lexical stresses where possible to S-positions), and then find that we have painted ourselves

You Like It 2.2.13); archaic depalatalization, mainly affecting words ending in -ion, -ious, -ient and so on, as in "The beachy girdle of the ocëan" (2H4 3.1.50), "Yet have I fierce affections, and think" (Antony and Cleopatra 1.5.22); and expanded preterites, as in "In the >rank sweat of an enseamëd bed" (Hamlet 3.4.102), "< High on a stage be placëd tŏ the view" (Ham. 5.2.397). Archaic desyncopation is relatively rare, and so to avoid clutter only the archaic long form should be marked in the text; expanded preterites and archaic depalalalizations, however, are sufficiently common to make it helpful to mark both forms: "By their oppress'd and fear-surprisëd eyes" (Hamlet 1.2.208).

7 There are three kinds of elision: syncopation, distinguishing the long and short forms of difference in "The petty diffërěnce, we yet not know" (Antony and Cleopatra 2.1.49) and "The fearful diffe rence orf incensëd kings" (KJ 3.1.243); syneresis, distinguishing the long and short forms of minion in " < Out of one side her happy miniön," (King John 2.1.392) and "Beaut ${ }^{\mathrm{e}}$ ous and swift, the min ${ }^{\mathrm{i}}$ ons of their race" (Macbeth 2.4.15); and synaloepha, which can blend adjacent vowels, distinguishing the long and short forms of being in "Be ${ }^{\mathrm{i}}$ g red, she loves him best; and beïng white" (Venus and Adonis 77). 
into a corner, with a forbidden final reversal: "Young, valiant, wise, and (no >doubt) right < royal". In both cases, pointing would have obviated the confusion: "Pernicious Protector, dang ${ }^{\mathrm{e}}$ rous Peer"; "Young, valiant, ' wise, and (no doubt) right ro' yal".

Where there are two elastic words in one line there may be two different paths to metrical congruity for the line as a whole: an editor cannot possibly note all these variations, and will need to make a choice of which to represent. Logically there is no need to be bound by copy-text here unless the difference between the two readings is immaterial; if, however, one contraction or expansion seems less outlandish to modern ears one might go with that, preferring (for example) "Can'st thou not ministĕr $\mathrm{t}^{\mathrm{o}}$ a mind diseas'd" to "Can'st thou not min ${ }^{\mathrm{i}}$ ster tŏ a mind diseas'd" (Macbeth 5.3.40). If the choice is not indifferent, one might want to choose the more complex metrical variant, by a version of difficilior lectio: where F1 Laertes blandly remarks of the plan to murder Hamlet "And yet 'tis almost 'gainst my conscience" (TLN 3769), Q2's version reveals something of an interior struggle by putting a kind of hesitant emphasis on the word almost, through forcing a reversal and a slight necessary exaggeration of the buffering phonological-phrase break that precedes it: "And yet it $\breve{s}$ < almost against my con'science." (5.2.296).

Whereas no editions currently indicate metrical switches, and the marking of stress-differences is usually confined to footnotes, marking of contractions (and some expansions) is still a feature of many modern editions, but it is inconsistent and incomplete: they generally mark expansion only in preterites, for example, they indicate some syncopations and synaloephas but no synereses, and they do not distinguish excision from elision. The rule I am suggesting, then, is that the choice between long and short forms should in general be determined by local metrical congruence rather than by the copy-text: even if Hamlet Q2 is our copy-text, we should prefer F1's congruent he is and I'd in "That he is mad, 'tis true: 'Tis true 'tis pittie," or "Hath there bene such a time, I'de fain know that," (Hamlet 2.2.97, 153; TLN 1125, 1183) over Q2's incongruent variants he's and I would (which Evans 1974 prints). This is not to assume that the choice does not in some cases affect meaning, and that there are not at times subtle differences in register between the long and short forms. Archaic depalatalizations, in particular, seem to have had a rather formal air: Morocco's "Mislike me not for my complexïon" is clearly meant to suggest a grand, exotic presence (compare Portia's dismissive "Let all of his complexi on choose me so" (Merchant of Venice 2.1.1, 2.7.80). Nevertheless, metre aside, function-word pairs like it is vs. 'tis/it's seem on the whole to be interchangeable: between Hamlet Q2 and F1, in five of the thirteen prose occurrences the two texts differ, which suggests that in terms of register they are equivalent. The most elevated speech in the play, "To be or not to be", contains two instances of 'tis, and the highly formal Murder of Gonzago contains three. Moreover, we may assume that where there is a meaningful difference in register the poet will have already taken that into account, and will have arranged the metre of the line to accommodate 
the appropriate form. The quiet menace of the carefully articulated dangërous in Hamlet's warning to Laertes - "Yet have I in me something dangërous" (5.1.262) - is presumably engineered by the poet: the metre here is providing a "stage-direction in shorthand".

Whether or not they are marked in the copy-text with apostrophes, for consistency syncopations and synaloephas will need to be registered with superscript vowels; due editorial caution suggests that in the case of function-word contractions that might be either excisions or elisions, we should give them as excisions if so marked in the copy-text, or in another witness, and otherwise as elisions.

At times, the marking of contraction in modern editions is just plain wrong. This is because orthographic contractions constitute accidentals, and in modern editing practice are subject to Greg's rule that "the copy-text should govern (generally) in the matter of accidentals" $(1950,21)$. Now there is nothing intrinsically wrong with this rule, so long as we can distinguish accurately between substantives and accidentals, although this distinction has become more problematic since Greg wrote - indeed, he began the process of problematization himself, while declining to take it further ${ }^{8}$ But the orthographic registration of contractions and expansions, though generally accidental for "the author's meaning" (21) 9 is substantive for the metre: specifically, an orthographic contraction that eliminates a necessary buffer will (unhelpfully for the reader) represent a line as unmetrical. In 6.3 for example, the is a buffer, and to elide it (as Q2 - but not Q1 or F1 - does) is quite simply to make a mistake, a mistake that Shakespeare's editors from Rowe to Jenkins found rather easy to obviate by following F1:

\begin{tabular}{c|c|c|cc|c|ccc|c}
\hline When & he & lay & couched & in & th'omynous & horse, \\
\hline O & o & a & A & o & o & öA & o & o & A \\
S & w & w & S & w & $\underline{\text { S }}$ & S & w & w & S \\
\hline
\end{tabular}

(a) Hamlet 2.2.454, Q2

\begin{tabular}{|c|c|c|c|c|c|c|c|c|c|}
\hline When & he & lay & \multicolumn{2}{|c|}{ couched } & in & the & \multicolumn{2}{|c|}{ Ominous } & horse, \\
\hline $\mathrm{O}$ & $\mathrm{O}$ & a & A & $\mathrm{o}$ & $\mathrm{O}$ & ö & A & $\mathrm{o}$ & A \\
\hline$S$ & $\mathrm{w}$ & $\mathrm{w}$ & $S$ & $\mathrm{w}$ & $S$ & $\mathrm{w}$ & S & W & $S$ \\
\hline
\end{tabular}

(b) F1 TLN 1496

Figure 6.3

\footnotetext{
8 "It will, no doubt, be objected that punctuation may very seriously 'affect' an author's meaning; still it remains properly a matter of presentation" (Greg 1950, 21n.).

9 "Generally" accidental for meaning because avoidance of contraction is sometimes meaningful, as with Hamlet's menacing trisyllabic "dangĕrous" at 5.1.262 (see above).
} 
Modern editors, however, generally take Q2 as their copy-text, and a surprising number of them (including Evans) follow Greg's rule here and perversely print the unmetrical th'ominous, even when they dutifully indicate the expanded status of couchëd. But the task of an editor is to remove error, not to preserve it: it is better there be no pointing at all in a line than that it preserve the erroneous pointing of a compositor.

The rule that the choice between long and short forms should be in general determined by local metrical congruence applies even where there are no actual variants. Since F1's orthographical syncopation of Macbeth's offerings in 6.4(a). for example, eliminates a necessary buffer and thus renders the line unmetrical, it was rightly ignored as an error by most editors from Alexander Pope to Jenkins (1982):

\begin{tabular}{c|cc|cc|c|cc|cc}
\hline Pale & Heccats & Offrings: & and & wither'd & Murther \\
\hline a & A & o & A & $\ddot{o}_{\text {o }}$ & o & A & o & A & o \\
w & S & w & S & w & $\underline{\text { S }}$ & S & $w$ & S & w \\
\hline
\end{tabular}

(a) Macbeth F1 TLN 632

\begin{tabular}{c|cc|ccc|c|cc|cc}
\hline Pale & Hecate's & \multicolumn{2}{|c|}{ Offerings: } & and & wither'd & Murder \\
\hline a & A & o & A & O & O & o & A & o & A & o \\
w & S & w & S & w & S & w & S & w & S & o \\
\hline
\end{tabular}

(b) 2.1.52, Pope et seq.)

Figure 6.4

Nevertheless, many modern editors (including Muir, Evans, Brooke, Braunmuller and Miola) insist on returning to the unmetrical off'rings of 6.4(a), in tin-eared deference to Greg's rule. None of these editors accepts F1's "I dare do all that may become a man, / Who dares no more, is none." (TLN 524-5); they all adopt Rowe's substantive emendation of no to do, because 525 as it stands, though grammatical, makes no sense in its context. Why, then, print metrical nonsense when it can be repaired by changing a mere accidental? This is truly what Greg called "the tyranny of the copy-text" $(1950,36)$.

This example (Rowe's dares do more) reminds us that despite their modern reputation for arbitrary high-handed emendation, those first editors and their conjectures have shaped much of what now constitutes a broad consensus on the text of Shakespeare. Pope's offerings should further remind us that some of those early editors, Pope not the least, were men who had an ear for pentameter (even if the prosodic constraints they expected were narrower than the ones Shakespeare allowed himself), and that their conjectures in this matter deserve at least to 
be considered with an open mind. R. A. Foakes, the Arden 2 editor of Henry VIII, having complained that F1's 6.5(a) is "rhythmically not very satisfactory" $(1957,116 n)$ rejects "Pope's addition of a comma after 'can' [as] needless, for the sense is good". As Wells has observed, where metre is concerned "[i]t is characteristic of modern practice that editors recognize the problem while shying away from the attempt to solve it" $(1984,53)$; Pope's comma indicates a reading with an intonational phrase-break after can, functioning as a buffer against the domination of can to restore the metrical congruence Foakes realized was lacking 10

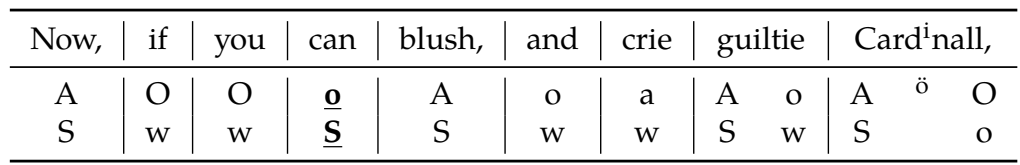

(a) Henry VIII 3.2.305

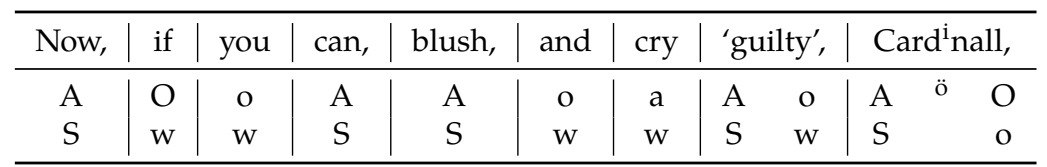

(b) Pope et seq.

Figure 6.5

As Greg once remarked, "where one reading is metrical and the other not [. . .] we have, I think, good and sufficient ground for judging" $(1966,287)$. Pope's solution was reproduced by Theobald, Warburton, Johnson and Steevens among others, but has been lost to modern editions.

A more complex example of the metrical wisdom of the ancients is Hamlet TLN 3577-9 (5.2.73-5). This passage is unique to F1, where it is printed as three lines, only one of them a pentameter (non-pentameters are preceded by an asterisk):

[A]

Ham. *It will be short,

The interim's mine, and a mans life's no more

Then to say one: but I am very sorry good Horatio,

Pope saw that one could up the count to two pentameters by splitting TLN

10 More technically, can in \#5b becomes (because of the intonational break) part of an ellipted verb phrase ("if you can [blush],") and needs no buffer because it carries the lexical stress necessary to any verb phrase. 
3579 (as in [B]), but it was the under-rated Thomas Hanmer (1744) who first noticed that the passage could be re-lineated as three pentameters by expanding interim's (3578) to interim is (thus restoring a crucial buffer before is):

[B]

The Int rim's mine, and a 'man's life's no more

Than to say, one.

But I am very sorry, good Hora $t^{i}$,

(Pope 1725)

$[\mathrm{C}]$

It will be short. The intërim is mine,

And a 'man's life's no more than to 'say, one.

But I am very sorry, good Hora' $t^{i}$,

(Hanmer 1744)

Hanmer's solution has been, since Steevens and Malone, the standard redaction of the lines (even Bate and Rasmussen accept it). Nevertheless, a number of recent editors such as Evans, Wells and Taylor, Edwards and Arden 3 print something like [D], retaining Hanmer's re-lineation but rejecting its rationale by crippling the first line as pentameter in the name (presumably) of Greg's rule:

[D]

It will be short. The interim's mine;

(Edwards 1985)

Edwards remarks: “The line is a syllable short. Editions universally mend it by printing 'interim is', but there is no authority for this" $(1985,240 \mathrm{n})$, and the Arden 3 editors quote this justification approvingly (Thompson and Taylor 2006, 472n). But the argument is incoherent: [D], the sacrosanct "line [that] is a syllable short", is the editor's own invention. If Hanmer's emendation of the lines metri causa is sufficient authority for Evans' and Edwards' re-lineation of F1, then it must also authorize the "mending" of a merely accidental contraction: both kinds of emendation - the relineation and the expansion of interim's have the same authority, the authority of the metre, and it is irrational to accept one and reject the other. There is, in any case, something perverse in clinging to a reading that you know subverts the metre precisely because you judge it to be unimportant, an accidental. As Stanley Wells says of a similar case, "[i]s this not an abnegation of editorial responsibility?" $(1984,51)$. 
But Pope and Hanmer are far from infallible guides for the modern editor, in that for historical reasons they never understood an important area of prosodic variation in Shakespeare's verse: catalexis, or the mapping of beats and offbeats onto silence (zero occupation of a syllable-position), which eighteenth-century editors attempted to "repair" by arbitrarily inserting words in the text. The line just before 6.4(b), for example, Pope gives as "The curtain'd sleep; now Witchcraft celebrates", arbitrarily inserting "now" to make up the tally of syllables. There are three kinds of catalexis, and thus three advanced diacritics (those which register features that require some degree of sophistication or instruction to recognize). The subscript caret ("^") for example, registers jolts, which are off-beats mapped onto breaks in the syntax, thus jerkily emphasising discontinuities where normal metre tends to minimize them and smooth them over; they function as (among other things) attention-getting surprises to underscore vocatives and imperatives:

\begin{tabular}{|c|c|c|c|c|c|c|c|c|c|}
\hline ^ & Go, & take & hence & that & \multicolumn{2}{|c|}{ traitor } & frŏm & our & sight, \\
\hline & A & a & A & $b$ & A & $\mathrm{O}$ & $\mathrm{O}$ & o & $A$ \\
\hline$\underline{\mathbf{w}}$ & $S$ & w & $S$ & w & $S$ & W & $S$ & w & $S$ \\
\hline
\end{tabular}

(a) Henry VI, Part 22.3 .100

\begin{tabular}{c|ccc|ccc|c|c|c|c}
\hline$\wedge$ & Gentlemen, & \multicolumn{2}{|c|}{ impórtune } & me & no & farther \\
\hline & A & o & O & o & A & o & O & o & A & o \\
$\underline{\mathbf{w}}$ & S & w & S & w & S & w & S & w & S & o \\
\hline
\end{tabular}

(b) Taming of the Shrew 1.1.48

\begin{tabular}{c|c|c|c|c|c|cc|ccc}
\hline But & room, & ^ & fairy! & Here & comes & \multicolumn{2}{|c}{ Oberon } \\
\hline o & A & & A & o & A & a & A & o & O \\
w & S & $\underline{\mathbf{w}}$ & S & w & S & w & S & w & S \\
\hline
\end{tabular}

(c) Midsummer Night's Dream 2.1.58

\begin{tabular}{|c|c|c|c|c|c|c|c|c|c|}
\hline$\hat{\imath}$ & Stay! & $\hat{\imath}$ & Speak, & $\hat{\imath}$ & speak, & I & charge & thee & speak! \\
\hline & A & & A & & A & $\mathrm{O}$ & S & O & A \\
\hline$\underline{\mathbf{w}}$ & $S$ & $\underline{\mathbf{w}}$ & S & $\underline{\mathbf{w}}$ & $S$ & W & $S$ & $\mathrm{~W}$ & $S$ \\
\hline
\end{tabular}

(d) Hamlet 1.1.51 
The tilde (" "), by contrast, represents a drag: an offbeat mapped onto a point within a phonological phrase where no syntactic break is possible, often between subordinated adjective and noun. The effect is legato rather than staccato, and tends to stretch out and to force accent (and thus emphasis, another stage direction in shorthand) onto the subordinated adjective so that it can function as a beat:

$<$ Now, if you have a station in the file,

\begin{tabular}{c|c|c|c|c|c|c|cc|c|c}
\hline$<$ Not & $\mathrm{i}^{\prime}$ & the & worst & $\sim$ & rank & of & manhood, & say & it, \\
\hline $\mathrm{O}$ & $\mathrm{o}$ & $\mathrm{o}$ & $\mathrm{a}$ & & $\mathrm{A}$ & $\mathrm{o}$ & $\mathrm{A}$ & $\mathrm{o}$ & $\mathrm{A}$ & $\mathrm{o}$ \\
$\mathrm{S}$ & $\mathrm{w}$ & $\mathrm{w}$ & $\mathrm{S}$ & $\underline{\mathbf{w}}$ & $\mathrm{S}$ & $\mathrm{w}$ & $\mathrm{S}$ & $\mathrm{w}$ & $\mathrm{S}$ & $\mathrm{o}$ \\
\hline
\end{tabular}

(a) Macbeth 3.1 .102

That very hour, and in the self-same inn,

\begin{tabular}{|c|c|c|c|c|c|c|}
\hline A & mean & $\sim$ & & tan & was & deliverĕd \\
\hline $\mathrm{o}$ & a & & & $\mathrm{O}$ & $\mathrm{O}$ & o A $\mathrm{A}$ \\
\hline $\mathrm{W}$ & $S$ & $\underline{\mathbf{w}}$ & S & $\mathrm{W}$ & S & $\mathrm{W} S \mathrm{~W} S$ \\
\hline
\end{tabular}

(b) Comedy of Errors 1.1.54)

He was a gentleman on whom I built

\begin{tabular}{|c|c|c|c|c|c|c|c|c|c|c|}
\hline An & absolute & $\sim$ & trust. & [Enter Macbeth] & $\mathrm{O}$ & & $\operatorname{th}^{\mathrm{i}}$ & & $\mathrm{col}$ & \\
\hline $\mathrm{O}$ & A $\quad$ o & & A & & A & A & & $\mathrm{o}$ & A & $\mathrm{o}$ \\
\hline $\mathrm{w}$ & $\mathrm{S} \quad \mathrm{w} S$ & $\underline{\mathbf{w}}$ & S & & $\mathrm{w}$ & $\mathrm{S}$ & $\mathrm{w}$ & & $S$ & $\mathrm{o}$ \\
\hline
\end{tabular}

(c) Mac. 1.4.14

Figure 6.7 
Finally, the inverted exclamation mark (" $i$ ") represents rests or silent beats, which like jolts occur in syntactic breaks, but which require some sort of gestural marking to be perceived: from 6.8(a), the slap Cleopatra gives her messenger (the stage direction is in F1), partly for his impertinent advice and partly for the manner of it (his prissy expanded patience), to 6.8(b) the shrug with which Iago just hints a fault, and hesitates dislike of Cassio, nicely performed by Bob Hoskins in the BBC Othello, to 6.8(c) an angry or impatient gesture from Othello - perhaps a stamping of his foot (for many more examples of all three, see Groves 2013, 82-125):

\begin{tabular}{c|cc|ccc|c|c|c|c|c}
\hline Good & madam, & \multicolumn{2}{|c|}{ patiĕnce! } & / & What & say & you? & i Strikes him \\
\hline a & A & o & A & $\ddot{O}$ & O & & a & A & o & \\
w & S & w & S & w & S & & w & S & w & s \\
\hline
\end{tabular}

(a) Antony and Cleopatra 2.5.63

\begin{tabular}{|c|c|c|c|c|c|c|c|c|c|c|}
\hline Is & he & not & & est? & 1 & i & & est, & my & lord? \\
\hline $\mathrm{O}$ & $\mathrm{O}$ & o & A & o & & & A & o & o & A \\
\hline$S$ & $\mathrm{w}$ & w & $S$ & $\mathrm{w}$ & & $\underline{\mathrm{S}}$ & $S$ & $\mathrm{w}$ & $\mathrm{w}$ & $S$ \\
\hline
\end{tabular}

(b) Othello 3.3.103

And he that is approv'd in this offence, ...

\begin{tabular}{c|c|c|c|c|c|c|c|c|c}
\hline Shall & lose & me. & $\mathbf{i}$ & ${ }^{<}$What! & in & a & town & of & war, \\
\hline $\mathrm{o}$ & $\mathrm{A}$ & $\mathrm{o}$ & & $\mathrm{A}$ & $\mathrm{o}$ & $\mathrm{o}$ & $\mathrm{A}$ & $\mathrm{o}$ & $\mathrm{A}$ \\
$\mathrm{w}$ & $\mathrm{S}$ & $\mathrm{w}$ & $\underline{\mathbf{S}}$ & $\mathrm{S}$ & $\mathrm{w}$ & $\mathrm{w}$ & $\mathrm{S}$ & $\mathrm{w}$ & $\mathrm{S}$ \\
\hline
\end{tabular}

(c) Othello 2.3.213

Figure 6.8 
Here is a brief passage, based on F1, to illustrate advanced pointing in action. Hamlet exclaims "My father! ; methinks I see my father", gesturing (perhaps pointing) on the rest, which alarms Horatio, who has in fact just seen Hamlet's father, so that he answers with a startled initial jolt. Hamlet replies with a swap that puts reassuring (or perhaps patronizing) emphasis on "mind's eye". To Horatio's claim to have seen him the previous night, Hamlet responds with two puzzled jolts: “`Saw? ^ who?":

HAMLET: Thrift, thrift, Horatiŏ: the fun ${ }^{\mathrm{e}}$ ral bak'd-'meats

Did coldly furnish forth the marriage ta(bles;

[...]

My father! ; methinks I see my fa(ther.

HORATIO: ^ Where, my lord?

HAMLET:

In my ' mind's eye, Hora ${ }^{\left(t^{i}\right.}$.

[...]

HORATIO: My lord, I think I saw him yesternight.

HAMLET: ^ Saw? ^ who?

HORATIO:

My lord, the king your falther.

(Ham. 1.2.182)

Not everyone will embrace all the suggestions I have made here, for a number of reasons, but nonetheless it is time for editors to reverse this modern neglect of metrical structure, and to make available to metrically less sophisticated readers and actors the wealth of information and performance direction locked up in the rhythmical ordering of Shakespeare's verse; to begin the process would be the mark of (if not a definitive edition) then a defining one, setting a new standard for others to follow. 


\section{Table of Symbols}

\begin{tabular}{|c|c|c|c|}
\hline \multicolumn{2}{|l|}{ Symbol } & Meaning & Example \\
\hline \multicolumn{4}{|l|}{ Basic Pointing } \\
\hline Apostrophe & ' & Excised vowel & $\begin{array}{l}{ }^{<} \text {Bold in the quarrel's right, } \\
{ }^{<} \text {rous'd to the encoun ter, (KL } \\
2.1 .54)\end{array}$ \\
\hline $\begin{array}{l}\text { Superscript } \\
\text { vowel }\end{array}$ & a & Elided vowel & $\begin{array}{l}\text { A lovely boy }{ }^{<} \text {stol }^{\mathbf{e}} \mathbf{n} \text { from an } \\
\text { Ind }^{\mathrm{i}} \text { an king; (MND 2.1.22) }\end{array}$ \\
\hline $\begin{array}{l}\text { Vowel with } \\
\text { dieresis }\end{array}$ & ä & $\begin{array}{l}\text { Non-elided vowel } \\
\text { (where elision might } \\
\text { be expected) }\end{array}$ & $\begin{array}{l}\text { Divinely bent to meditation; } \\
\text { (R3 3.7.62) }\end{array}$ \\
\hline $\begin{array}{l}\text { Vowel with } \\
\text { acute }\end{array}$ & á & $\begin{array}{l}\text { (Unexpectedly) } \\
\text { stressed vowel }\end{array}$ & $\begin{array}{l}<\text { Making the hard way sweet } \\
\text { and délectă } \text { ble: (R2 2.2.7) }\end{array}$ \\
\hline
\end{tabular}

Advanced pointing (metrical, superscripted)

\begin{tabular}{|c|c|c|c|}
\hline $\begin{array}{l}\text { Left angle } \\
\text { bracket }\end{array}$ & $<$ & Beat of reversed foot & $\begin{array}{l}\text { Then Hamlet does it not, } \\
<\text { Hamlet denies (it. (Ham. } \\
\text { 5.2.236) }\end{array}$ \\
\hline $\begin{array}{l}\text { Right angle } \\
\text { bracket }\end{array}$ & $>$ & $\begin{array}{l}\text { Beat of swap (between } \\
\text { feet) }\end{array}$ & $\begin{array}{l}\text { The perfect cerëmŏny of } \\
\text { >love's rite (Son. 23.6) }\end{array}$ \\
\hline $\begin{array}{l}\text { Vowel with } \\
\text { breve }\end{array}$ & $\breve{a}$ & $\begin{array}{l}\text { Weak (unstressed) } \\
\text { beat }\end{array}$ & $\begin{array}{l}\text { The Earl of Sál'sbüry̆ } \\
<\text { craveth supply }(1 H 61.1 .159)\end{array}$ \\
\hline Left lunette & ( & $\begin{array}{l}\text { Extra weak ('femi- } \\
\text { nine') syllable at end } \\
\text { of segment }\end{array}$ & $\begin{array}{l}\text { And by opposing end (them? } \\
\text { To die, to sleep (Ham. 3.1.61) }\end{array}$ \\
\hline \multicolumn{4}{|c|}{ Advanced pointing (prosodic, subscripted) } \\
\hline $\begin{array}{l}\text { Subscript } \\
\text { caret }\end{array}$ & . & $\begin{array}{l}\text { Jolt (silent offbeat at } \\
\text { break) }\end{array}$ & $\begin{array}{l}\text { Let me tell you, Cass }{ }^{\mathrm{i}} \text { us, you } \\
\text { yourself (JC 4.3.9) }\end{array}$ \\
\hline Subscript tilde & $\sim$ & $\begin{array}{l}\text { Drag (silent offbeat at } \\
\text { non-break) }\end{array}$ & $\begin{array}{l}\text { Say his long } \sim \text { trouble now } \\
\text { is pa'ssing, (H8 4.2.162) }\end{array}$ \\
\hline $\begin{array}{l}\text { Inverted excla- } \\
\text { mation point }\end{array}$ & $i$ & $\begin{array}{l}\text { Rest (silent gestural } \\
\text { beat at break) }\end{array}$ & $\begin{array}{l}<\text { Think on Lord Hastings. } \\
\text { ¡ Despair and die! (R3 5.3.156) }\end{array}$ \\
\hline
\end{tabular}




\section{Bibliography}

Barton, John. 1984. Playing Shakespeare: An Actor's Guide. New York and London: Methuen.

Bate, Jonathan and Eric Rasmussen, eds. 2007. William Shakespeare: Complete Works. The RSC Shakespeare. Basingstoke: Macmillan.

Bevington, David, 1992. The Complete Works of Shakespeare. $4^{\text {th }}$ ed. New York: HarperCollins .

Braunmuller, A. R., ed. 1997. Macbeth. The New Cambridge Shakespeare.

Cambridge: Cambridge University Press.

Brooke, Nicholas, ed. 1990. Macbeth. The Oxford Shakespeare. Oxford: Oxford University Press.

Daniel, Samuel. 1603. "A Defence of Ryme: Against a Pamphlet Entituled:

Obseruations in the Art of English Poesie." A Panegyrike Congratulatorie. London: Imprinted [by R. Read] for Edward Blount.

Edwards, Philip, ed. 2003. Hamlet. The New Cambridge Shakespeare.

Cambridge: Cambridge University Press.

Evans, G. Blakemore, ed. 1974. The Riverside Shakespeare. Boston: Houghton.

Foakes, R. A., ed. 1957. King Henry VIII. Arden Shakespeare, $2^{\text {nd }}$ series. London: Methuen.

Gascoigne, George. 1575. “Certayne Notes of Instruction Concerning the Making of Verse or Ryme in English" in The Posies of George Gascoigne Esquire. London: For Richard Smith, pp. 291-300.

Greg, W. W. 1950. “The Rationale of Copy-Text”. Studies in Bibliography, 3, pp. 19-36.

—_. 1966. Collected Papers. Ed. J. C. Maxwell. Oxford: Clarendon Press.

Groves, Peter L. 1998. Strange Music: The Metre of the English Heroic Line. ELS Monograph Series 74. Victoria, BC: University of Victoria.

—. 1999. "The Chomsky of Grub Street: Edward Bysshe and the Triumph of Classroom Metrics", Versification: An Interdisciplinary Journal of Literary Prosody 2 <http:/ / www.arsversificandi.info/backissues/vol3/essays / groves.html> 
—. 2007. "Shakespeare's Pentameter and the End of Editing". Shakespeare: Journal of the British Shakespeare Association, 3, pp.126-42.

—. 2013. Rhythm and Meaning in Shakespeare's Verse: A Guide for Readers and Actors. Melbourne: Monash University Publishing.

Hinman, Charlton. 1955. "Cast-off Copy for the First Folio of Shakespeare". Shakespeare Quarterly, 6, pp. 259-73.

Hanmer, Sir Thomas, ed. 1744. The Works of Mr William Shakespear. In Six Volumes. Oxford: Printed at the Theatre.

Jenkins, Harold, ed. 1982. Hamlet. Arden Shakespeare, $2^{\text {nd }}$ series. London: Methuen.

Miola, Robert S., ed. 2004. Macbeth. Norton Critical Edition. New York: Norton.

Muir, Kenneth, ed. 1951. Macbeth. Arden Shakespeare, $2^{\text {nd }}$ series. London: Methuen.

Pope, Alexander, ed. 1725. The Works of Shakespear in Six Volumes, Collated and Corrected by the Former Editions. London: Jacob Tonson.

Thompson Ann, and Neil Taylor, eds. 2006. Hamlet. The Arden Shakespeare, $3^{\text {rd }}$ series. London: Thomson Learning.

Wells, Stanley, 1984. Re-Editing Shakespeare for the Modern Reader. Oxford: Clarendon Press.

Wells, Stanley, and Gary Taylor, eds. 1986. William Shakespeare: The Complete Works. Oxford: Clarendon Press.

—. 1987. William Shakespeare: A Textual Companion. Oxford: Clarendon Press.

Whitworth, Charles. 1991. "Rectifying Shakespeare's Errors: Romance and Farce in Bardeditry". In Ian Small and Marcus Welsh (eds.), The Theory and Practice of Text-editing: Essays in Honour of James T. Boulton. Cambridge: Cambridge University Press, pp. 107-41. 